Landslides (2018) 15:5-19

DOI 10.1007/s10346-017-0861-4

Received: 6 April 2017

Accepted: 7 July 2017

Published online: 17 July 2017

(c) The Author(s) 2017

This article is an open access publication
A. Rosi - V. Tofani - L. Tanteri - C. Tacconi Stefanelli - A. Agostini - F. Catani - N. Casagli

\section{The new landslide inventory of Tuscany (Italy) updated with PS-InSAR: geomorphological features and landslide distribution}

\begin{abstract}
In this paper, the updating of the landslide inventory of Tuscany region is presented. To achieve this goal, satellite SAR data processed with persistent scatter interferometry (PSI) technique have been used. The updating leads to a consistent reduction of unclassified landslides and to an increasing of active landslides. After the updating, we explored the characteristics of the new inventory, analysing landslide distribution and geomorphological features. Several maps have been elaborated, as sliding index or landslide density map; we also propose a density-area map to highlight areas with different landslide densities and sizes. A frequency-area analysis has been performed, highlighting a classical negative power-law distribution. We also explored landslide frequency for lithology, soil use and several morphological attributes (elevation, slope gradient, slope curvature), considering both all landslides and classified landslide types (flows, falls and slides).
\end{abstract}

Keywords Landslide · Inventory · PS

InSAR $\cdot$ Frequency $\cdot$ Distribution

\section{Introduction}

Landslides are a complex natural phenomenon that constitutes a serious natural hazard in many countries (Brabb and Harrod 1989). Landslides also play a major role in the evolution of landforms. Landslides are commonly associated with a trigger, such as an earthquake, a rapid snowmelt or an intense rainfall, with landslide areas spanning more than eight orders of magnitude and landslide volumes more than 12 orders (Malamud et al. 2004a).

Landslide databases, or digital landslide inventories, constitute a detailed register of the distribution and characteristics of past landslides (Hervás 2012).

Landslide inventory maps are prepared for multiple scopes (Brabb 1991), including (i) documenting the extent of landslide phenomena in areas ranging from small to large watersheds (e.g. Cardinali et al. 2001) and from regions (e.g. Brabb and Pampeyan 1972; Antonini et al. 1993; Duman et al. 2005) to states or nations (e.g. Delaunay 1981; Radbruch-Hall et al. 1982; Brabb and Harrod 1989; Cardinali et al. 1990; Trigila et al. 2010); (ii) as a preliminary step toward landslide susceptibility, hazard and risk assessment (e.g. Cardinali et al. 2002, 2006; Guzzetti et al. 2005, 2006a, b; Van Westen et al. 2006, 2008; Bălteanu et al. 2010); (iii) to investigate the distribution, types and patterns of landslides in relation to morphological and geological characteristics (e.g. Guzzetti et al. 1996); and (iv) to study the evolution of landscapes dominated by mass-wasting processes (e.g. Hovius et al. 1997; Malamud et al. 2004a, b; Parker et al. 2011). The last two points are quite important since it can provide important information on the geological and geomorphological control on landslide initiation. In particular, the frequency distribution analysis of landslide areas is already widely discussed issue (Fujii 1969; Hovius et al. 1997; Guzzetti et al. 2002; Dussauge-Peisser et al. 2002; Dussauge et al. 2003; Dai et al.
2010). For large and medium-sized landslides, landslide frequency distributions are generally negative power-law (scale-invariant) functions of the landslide area (Van Den Eeckhaut et al. 2007).

The landslide inventory can give insight into landslide location, type, dates, frequency of occurrence, state of activity, magnitude or size, failure mechanisms, causal factors and damage caused (Fell et al. 2007). Landslide inventories generally fall into two classes (Malamud et al. 2004b): (i) landslide-event inventories that are associated with a trigger and (ii) historical (geomorphological) landslide inventories, which are the sum of one or many landslide events over time in a region. A characteristic of historical landslide inventories is that evidence of the existence of many of the smaller landslides has been lost due to various degrees of modification by subsequent landslides, erosional processes, anthropic influences and vegetation growth.

Landslide inventory maps are produced using conventional (consolidated) methods and new (innovative) techniques (Guzzetti et al. 2012). Conventional methods used to prepare landslide maps include (i) geomorphological field mapping (Brunsden 1985) and (ii) the visual interpretation of stereoscopic aerial photographs (Rib and Liang 1978; Brunsden 1993; Turner and Schuster 1996). Geomorphologists are exploiting recent and new methods and technologies to help detect, map and update landslides over large areas. These new methods can be summarized in the following (Guzzetti et al. 2012): (i) analysis of surface morphology, chiefly exploiting very-high resolution digital elevation models (DEMs); (ii) interpretation and analysis of satellite images, including panchromatic, multispectral and synthetic aperture radar (SAR) images; and (iii) the use of new tools to facilitate field mapping.

Landslide detection and mapping benefit from both optical and radar imagery. Recently, a new generation of high resolution satellites as World View, Geo-eye and the Pleiades constellation provides resolutions ranging from 0.5 to $2 \mathrm{~m}$ and offers a very powerful tool for a quick reproduction of regional inventory maps (up to a scale of 1:2000) (Tofani et al. 2014). In particular, the increasingly higher spatial and temporal resolution of optical satellite observations enables (i) more detailed and reliable identification of affected areas, (ii) an immediate response minimizing the risk of omission (due to landslide traces fading away with time) and (iii) repeated observations potentially leading to multitemporal inventories, which can be easier related to specific events. There is a large number of studies which proposed, applied and compared automated (both pixel and object-based) techniques for landslide mapping with optical data (Hervás et al. 2003; Cheng et al. 2004; Nichol and Wong 2005; Martha et al. 2010; Lu et al. 2011).

Also, the application of the interferometric techniques to radar images is a powerful tool for landslide detection and mapping at large scale and can contribute to the creation and updating of landslide 
inventory maps. In particular, A-DInSAR techniques such as PSInSAR (Ferretti et al. 2000; Colesanti et al. 2003), SqeeSAR (Ferretti et al. 2011), Stanford Method for Persistent Scatterers (StaMPS) (Hooper et al. 2007), Interferometric Point Target Analysis (IPTA) (Werner et al. 2003; Strozzi et al. 2006), Coherence Pixel Technique (CPT) (Mora et al. 2003), Small Baseline Subset (SBAS) (Berardino et al. 2003; Casu et al. 2006) and Stable Point Network (SPN) (Crosetto et al. 2008; Herrera et al. 2011) have produced some successful case studies dealing with the detection and the mapping of landslide phenomena, as discussed in Strozzi et al. (2006), Colesanti and Wasowski (2006), Lu et al. (2012), Meisina et al. (2013), Agostini et al. (2014), Ciampalini et al. (2016), Righini et al. (2012) and Raspini et al. (2017). Recently, images captured by X-band radar satellite sensors such as the Italian COSMO-Sky Med SAR constellation of four satellites, the German TerraSAR-X satellite and the recently lunched ESA Sentilel-1 can provide very high ground resolution, in the range from 1 to $100 \mathrm{~m}$, and a reduced revisiting time, up to 6 days for Sentinel-1.

In this work, we present the distribution and the geomorphological features of the landslide inventory of the Tuscany region, in Italy. The original landslide database was realized by the Tuscany region administration in the early 2000. In 2010, the database has been updated through PS-InSAR data, making use of ERS1/2 and ENVISAT images spanning a time interval from 1992 to 2010. The final inventory counts about 91.700 landslides, where one landslide can be represented by one or more polygons (in case of landslides characterized by different styles or rates of movements).

The objective of this work is to make an analysis of the landslide inventory characteristics and in particular: (i) analysis of the geographical distribution of the landslides in the Tuscany region with respect to the number and size of landslides, (ii) areafrequency distribution and (iii) analysis of the morphological and geological properties of landslides.

The outcomes of this work can provide important information of the geomorphological and geological control on landslide initiation, and it can be of help for any further hazard and risk analysis.

\section{Study area}

The study about the development of ground movement databases was conducted on the whole extension of Tuscany region, in central Italy. Tuscany extends on $22.994 \mathrm{~km}^{2}$ between the regions of Emilia-Romagna, Marche, Umbria and Lazio, also including a little island archipelago composed by six main islands and other small ones.

Tuscany is divided administratively into 10 provinces and 287 municipalities, the regional capital is Florence (the most populated city with about 373,000 inhabitants) and the other provincial capitals are Arezzo, Siena, Grosseto, Pisa, Livorno, Massa, Pistoia, Prato and Lucca (Fig. 1).

The territory is characterized by extremely various landscape morphology, from the Thyrrenian coastal plains, in the western part, up to the Apenninic ridge that runs on the border of the region from NW to SE, with heights even greater than $2000 \mathrm{~m}$ a.s.l. (Monte Prado, $2054 \mathrm{~m}$ a.s.l.), where the topography pattern is typical of mountainous areas. The central part of the region includes hilly areas and flat territories or wide valley floors where the main rivers flow.

As a whole, the climate of Tuscany is typically Mediterranean (Köppen classification, $\boldsymbol{C s} \boldsymbol{a}$ ), characterized by mild and moist winters and hot and dry summers, but it is possible to recognize several areas with different climatic peculiarities, depending on the position with respect to orographic elements and the coast, as well as vegetation coverage and internal water bodies. The major rainfall and snowfall values are concentrated in the Northern part, along the Apennine ridge, that is an orographic barrier for atmospheric perturbations, leading to mean annual precipitations up to $2000 \mathrm{~mm} /$ year in correspondence of the Apuan Alps and the Garfagnana zone (provinces of Lucca and Massa-Carrara). Indeed, these areas, as well as the Mount Amiata and surroundings, show the major concentration of landslide phenomena. In southern Tuscany, low rainfall amounts are instead recorded, due to the lack of reliefs able to generate orographic effects. In the Maremma plain, the recorded rainfall amounts are usually lower than $600 \mathrm{~mm} /$ year with low peaks of ca. $400 \mathrm{~mm}$ /year (Rosi et al. 2012).

The geological setting of the region is strictly correlated with the overall Northern Apenninic scenario. The Apennines mountain range was originated by the overlapping of three main geological units: the Ligurian unit that overlaps the Tuscan unit that, in turn, overlaps the Umbro-Marchigian unit (Bortolotti 1992; Vai and Martini 2001, Fig. 2).

The aforementioned units belong to different paleo-geographic domains, called Ligurian, Sub-Ligurian, Tuscan and UmbroMarchigian, related to their position with respect to the Jurassic ocean Ligurian-Piedmontese.

The Ligurian domain consists in several tectonic units in which deposits are parts of Jurassic oceanic lithosphere (ophiolites, gabbric rocks and pillow basalts) and its sedimentary coverage, deposed between Malm and middle Eocene.

The Sub-Ligurian domain is characterized by sedimentary rocks with unknown substratum. On the base of the geometrical position within the structure of the Apennines and stratigraphical considerations, these units are considered as the results of the deposition of sediments in a transition area between the Ligurian ocean crust and the continental crust (Adria tectonic plate).

The Tuscan domain is substantially composed by two units: the Metamorphic Tuscan Units and the Non-Metamorphic Tuscan Units.

The Non-Metamorphic are Mesozoic-Tertiary deposits of various kinds, originated on a continental basement, such as coral reef limestones, pelagic sediments, turbidites. The Metamorphic units are underlying the previous and crop out in the Apuan Alps (called Apuan tectonic window). The Umbro-Marchigian units consist in a sedimentary sequence that lies on continental crust of the Adria plate but unstuck from it in correspondence of the basal evaporitic layers.

\section{Materials and methods}

\section{Available data}

This work moved from an initial landslide inventory containing 91,366 landslides, each one associated to its proper movement direction, state of activity, type of movement (according to the WP-WLI glossary, WP/WLI, 1993), perimeter length and area, for the entire territory of Tuscany region.

It was formerly obtained by the integration of different landslide inventories, such as Basin Authorities Inventories, Geological Maps and Municipal Structural Plans.

This inventory has been updated by the use of several kinds of data, as described in the following paragraphs. 


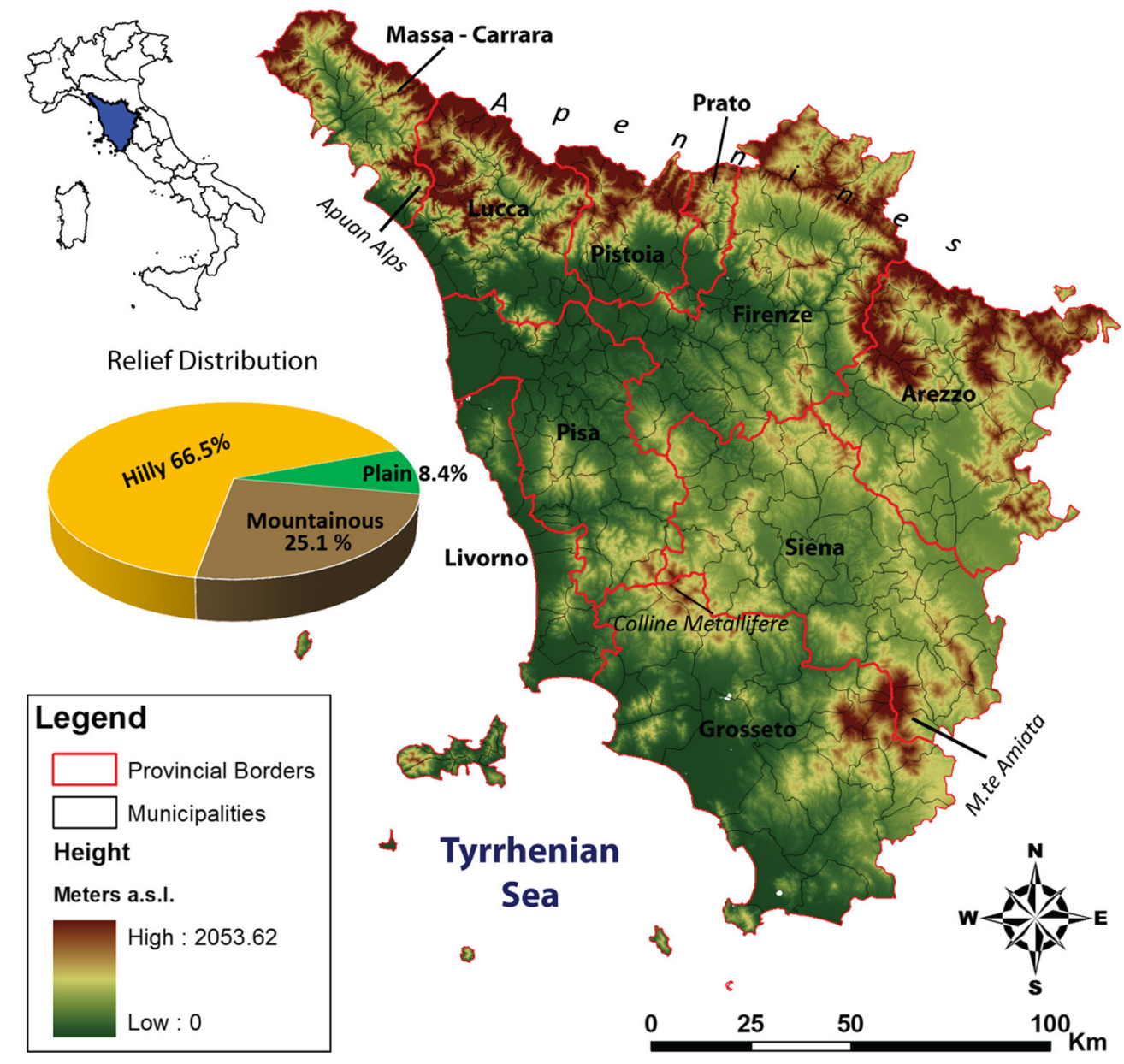

Fig. 1 Location of study area. In bold the names of provinces, in italic the names of places cited in the text

Available data are topographic, geological and terrain datasets, each one fundamental for the interpretation of particular features related to ground motion areas, integrated by PSInSAR data, which is a well-known technique to map and monitor landslides.

In particular, the following data have been used:

- Regional Topographic Map (CTR) at scale 1:10,00o, provided by the Geological Survey of Tuscany Region.

- A Digital Terrain Model (DTM) covering the entire Tuscany Region with $10 \mathrm{~m}$ of spatial resolution.

- RGB images covering the entire Tuscany Region with $1 \mathrm{~m}$ of spatial resolution, acquired in 2012 and available in http:// www.pcn.minambiente.it.

- Regional Geological Map.

In this work, radar interferometric data processed with the Persistent Scatterers Interferometry (PSI) technique were also used.

Radar satellite data are widely used in mapping and characterizing ground motions on the earth surface (Colesanti and Wasowski 2006; Colesanti et al. 2003; Farina et al. 2006; Lu et al. 2012; Vilardo et al. 2009; Rosi et al. 2014, 2016).
The data used in this work were acquired by the satellites ERS12, covering a time span between 1992 and 2000, ENVISAT, referred to a time interval between 2002 and 2010 (Table 1).

All these satellites were provided by European Space Agency (ESA) and equipped with radar C-band sensors. The related interferometric data used for the detection of slow kinematics ground movements in Tuscany were included in the "Piano Straordinario di Telerilevamento Ambientale" (Extraordinary Plan of Environmental Remote-sensing) and were distributed by the Ministry of Environment and Territory of the Sea (METS).

Since ERS 1/2 satellites have been active between 1992 and 2000 while ENVISAT from 2002 to 2010, it has been possible to have 18 years of almost continuous information about the temporal evolution of the displacements, in all the areas in which PS were present.

On the one hand, the overall spatial coverage on the Tuscany region is widely incomplete regarding ERS satellite data, which cover the whole region in descending orbit but only a small area in ascending orbit (Fig. 3).

On the other hand, ENVISAT data cover the entire regional territory, allowing to carry out a complete analysis on the whole study area. 


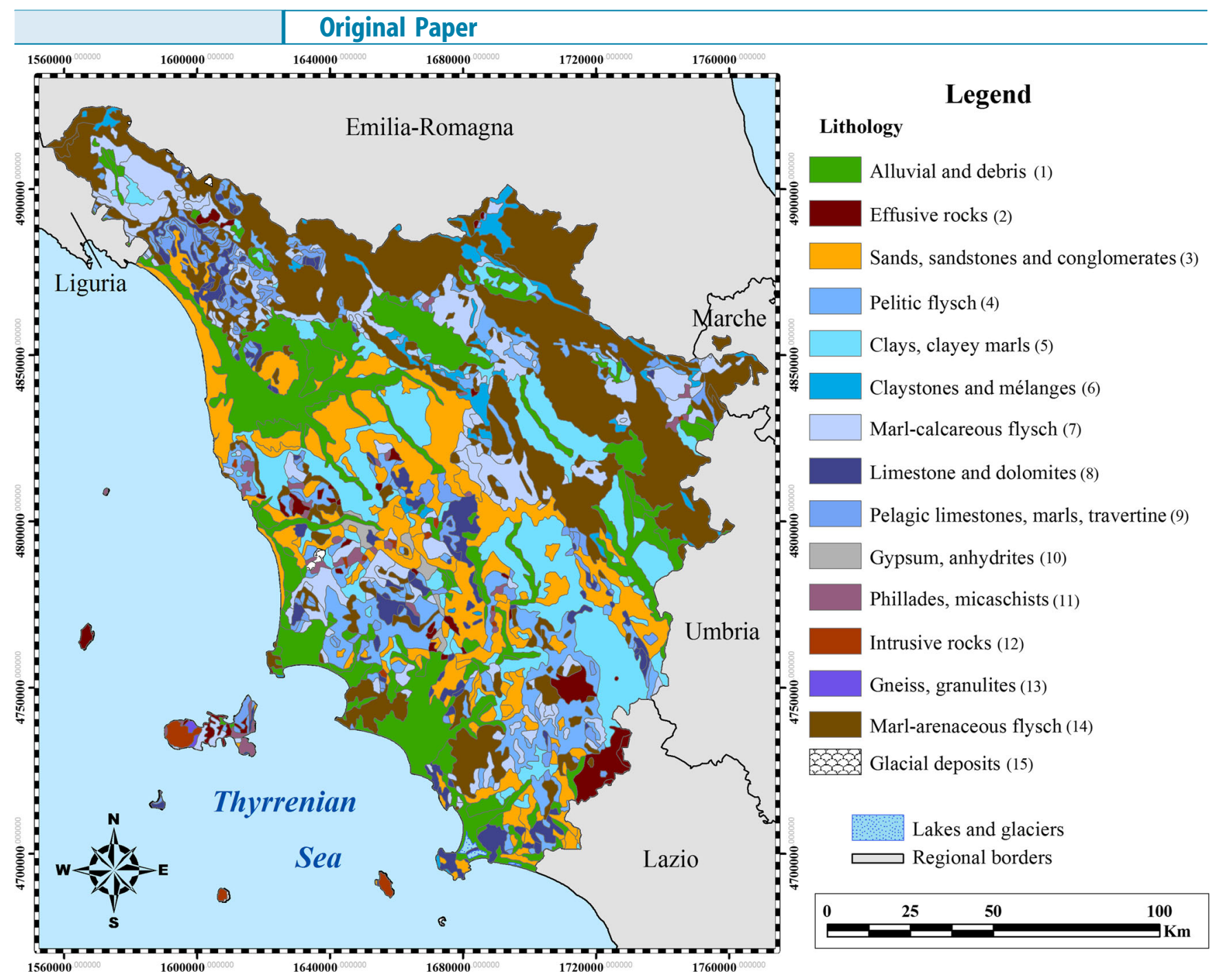

Fig. 2 Lithological map of Tuscany (scale 1:100,000), from Bicocchi et al. 2016, modified. Numbers represent lithological classes used in the subsequent analyses

\section{Updating the inventory}

The preliminary mapping of instable areas has been carried out through radar-interpretation, which consists in the integration of the interferometric measurement of ground motion and the information contained in the ancillary data and a following synthetic assessment of the scenarios.

Figure 4 shows the methodology adopted for the updating of the Tuscany Landslide Inventory Map, starting from the acquisition and integration of the available data, through the interpretative stages, until the result validation based on field surveys.
By integrating PSI and ancillary data, it has been possible to modify the features of the landslides already included in the inventory or to detect new phenomena.

For the interpretation of PS measurements, velocity values that range between +1.5 and $-1.5 \mathrm{~mm}$ per year are conventionally considered as stable. This stability range has been provided by the Italian ministry as well as the PS data.

Four activity classes are established: stabilized, active, dormant and relict. Such classes are defined according to the Multilingual Landslide Glossary (WP/WLI 1993) and sep-

Table 1 Characteristics of the interferometric data

\begin{tabular}{|llcrr}
\hline Satellite & Orbit & Acquisition period & No. images & Density $\left(\mathrm{PS} / \mathrm{km}^{2}\right)$ \\
\hline ERS 1-2 & Ascending & $1992-2000$ & 26 & 4.9 \\
\cline { 2 - 5 } & Descending & $1992-2000$ & 61 & 30.2 \\
\hline Envisat & Ascending & $2002-2010$ & 41 & 49.7 \\
\cline { 2 - 5 } & Descending & $2002-2010$ & 41 & 58.9 \\
\hline
\end{tabular}




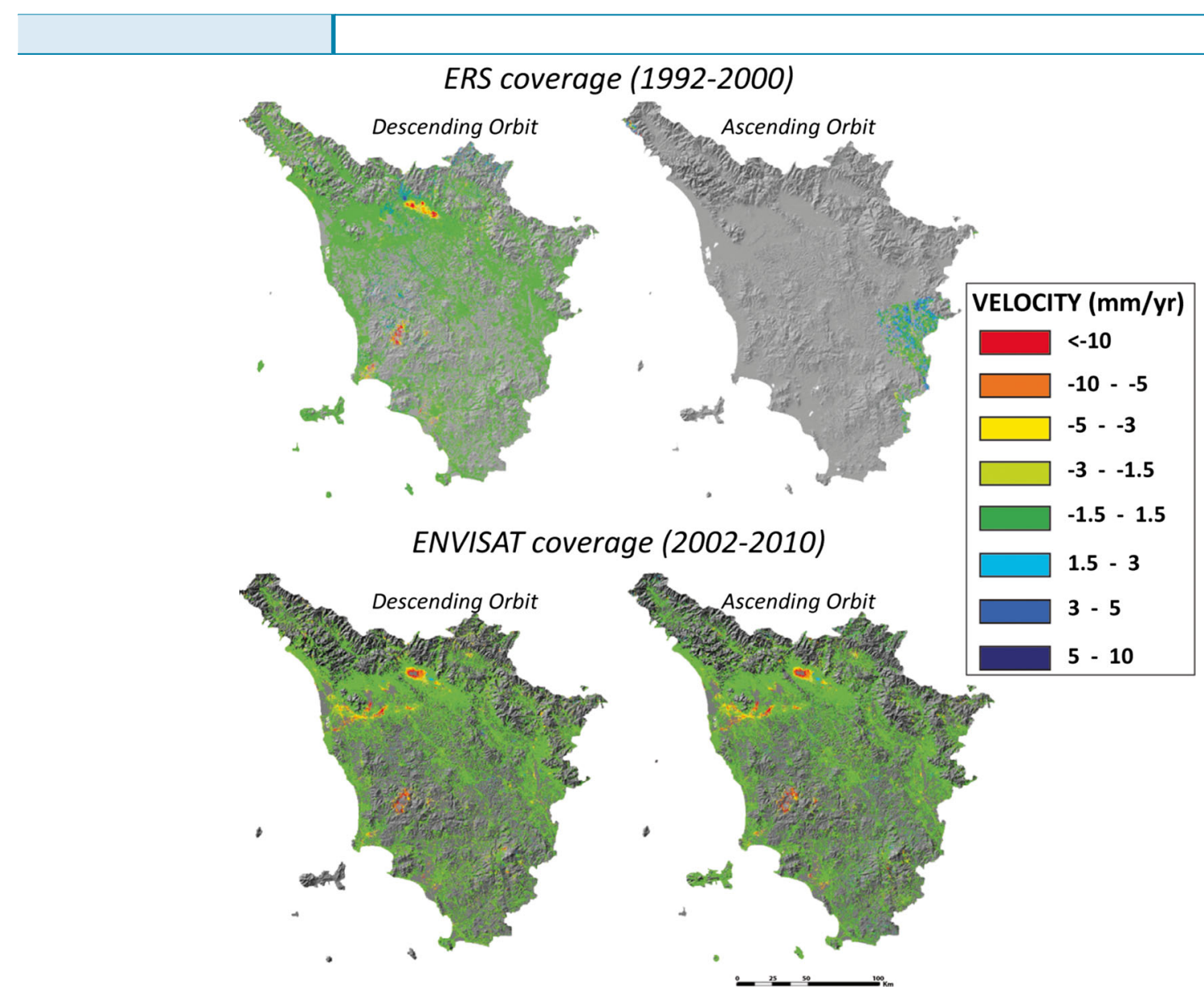

Fig. 3 Data coverage of ERS and Envisat satellites

arated by the threshold value $\pm 1.5 \mathrm{~mm}$ /year. To define these classes, the approach firstly proposed by Righini et al. (2012) has been used.
The final product is a new landslide inventory map in shapefile format, with new fields in the attribute table, related to the modifications applied to each polygon.

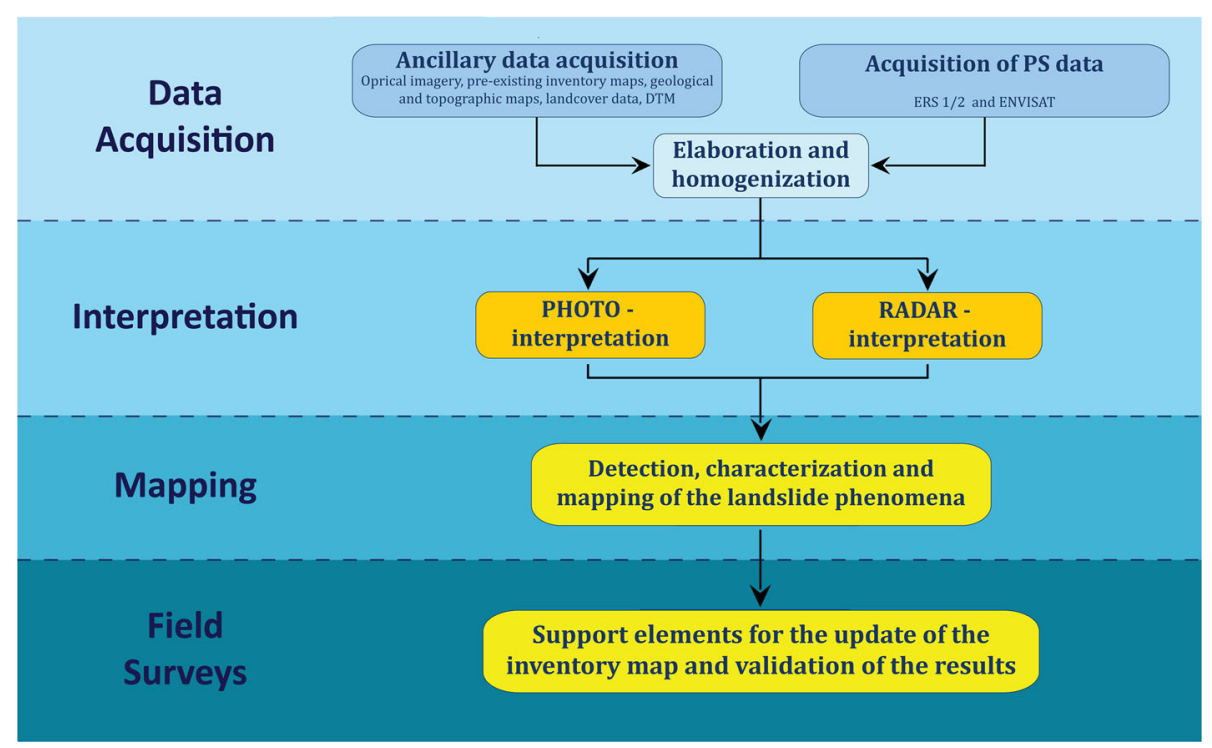

Fig. 4 Schematic flowchart of the methodology adopted for the updating of Tuscany Landslide Inventory 
In particular, in all the cases in which the PSI technique has proved to be efficient, the radar-interpretation approach has allowed to modify or assess (in case of new detected phenomena) the following attributes:

- Area and perimeter

- Landslide type (according to Cruden and Varnes 1996)

- Displacement velocity, during the acquisition period.

- State of activity.

To define extension and type of landslides, only PSI data cannot be used, but it is also necessary to consider other data as topographic maps or digital terrain model. To modify the state of activity or to add a new landslide, the presence of two or more PSs was necessary.

It is worth to specify that, in several cases, it has been impossible to modify or characterize the attribute "Landslide Type" since this consideration needs for further and more detailed analyses (mainly filed surveys).

\section{Results}

\section{Updated inventory}

Of the whole initial inventory, only ca. 4400 landslides had enough PS (at least two PSs, independently from the satellite or the orbit) for their updating.

By the radar interpretation, the initial landslide inventory has been updated and 364 new landslides have been detected and mapped, 1904 landslides have been modified (activity state, perimeter, etc.), leading to an inventory with ca. 91,700 landslide polygons, for a total of $2107 \mathrm{~km}^{2}$ of landsliding areas. Slides are the main type of landslides in the new inventory (39\%), followed by flows $(14 \%)$ and fall $(1 \%)$, but in the $46 \%$ of cases it was not possible to properly classify the landslides (Fig. 5).

The new inventory, compared to the previous one, shows an increasing of active and dormant landslides and a reduction of stabilized and with undefined activity landslides (Table 2), as reported in the following table, where the previous and the updated inventory have been compared, both in number and in area of landslides.

\section{Landslide distribution}

After the inventory updating, an accurate analysis of landslide distribution and characteristics, related to the morphology of Tuscany, has been performed.

Area/frequency distribution has been initially investigated and showed that landslides are log-normally distributed and tend to follow an inverse power law over several orders of magnitude (Dai and Lee 2001; Fujii 1969; Guzzetti et al. 2002, 2005; Malamud et al. $2004 \mathrm{a}, \mathrm{b}$ ), with a rollover starting at ca. 10,000 $\mathrm{m}^{2}$ (Fig. 6).

The spatial distribution of landslides has been investigated as well, by calculating the landslide density and the sliding index of each of the 287 municipalities of Tuscany (Fig. 7a, b). Landslide density is the number of landslides for $\mathrm{km}^{2}$ and give useful information about more landslideprone areas, independently from administrative boundaries. The "sliding index" is a common tool to assess the landslide distribution at small scale (Romeo et al. 2006). The index is calculated as the ratio between the landsliding surface and the area of each municipality.
Both landslide density and sliding index show that the most landsliding areas are in correspondence of the main relieves of the region: Apuan Alps to the North, Apennines in Nort-East and M.te Amiata to the South.

In addition to landslide distribution, another important parameter to consider in urban planning is landslide size, since different sized landslides lead to different problems and require different mitigation works. Therefore, for planning purpose, it could be very important to identify areas with higher number of small landslides, which need regular upkeep works, and with bigger mass movements, which require a careful investigation and project phases. An effective identification of these areas can considerably reduce the maintenance and reconstruction costs due to landslides.

To this purpose, a single map, displaying both landslide density and dimension distribution, is proposed.

As shown in Fig. 8, the Tuscan territory was divided in squares of $25 \mathrm{~km}^{2}$ that display, in a single image, the spatial distribution of the number of mass movement (expressed as landslide density) and the mean landslide areas in each square.

These parameters were connected together using a colour scale that is the result of the combination between the simple colour scales of the two landslide parameters. Both parameter scales are divided into four classes (from 1 to 4 for increasing landslide density and from "a" to " $\mathrm{d}$ " for increasing landsliding area), resulting in a total of 16 classes, ranging from 1a (low density of small landslides) to $4 \mathrm{~d}$ (high density of large landslides). The size of the classes for landslide density and dimension distribution has been chosen according to the Jenks natural breaks classification method (Jenks 1967), to define the best value distribution between the classes.

The result of regional classification shows that the northwestern section of the Apennines (Massa, Lucca and part of Pisa and Pistoia Provinces) and in lesser extent the western area of the region (Siena and Grosseto Provinces) is mainly characterized by high density but small dimension landslides. Large landslides with low density are focused in three different areas, the north-eastern part of the Apennines (Florence and Arezzo Provinces), the "Colline Metallifere" mountain chain (between Siena, Pisa and Grosseto Provinces) and the north-eastern area of the Amiata Mountain (Siena Province). Areas characterized by high density of large landslides are irregularly distributed through the region along the "Colline Metallifere" mountain chain and the northern part of the Apennines. In the southwestern part of the Amiata Mountain instead, this kind of distribution is more concentrated. The coastal plains, as should be expected, are characterized by a low density of small landslides. The same is for the internal plains like the Florence-Prato-Pistoia basin and the Val di Chiana plain.

\section{Morphological features}

After the analysis of landslide distribution, the work focused to analyse the relation between landslides and several geological and morphological features, such as elevation, slope inclination or soil use.

First, analysis was focused on the lithologies (Fig. 9) involved by landslides, using the lithological map of Tuscany (scale 1:100,000). We explored the landslide area for each lithology; then, the analysis was focused on the three main types of landslide (Fig. 9a), analysing both the landslide types for each lithology (Fig. 9b) and the distribution of lithologies for each landslide type 


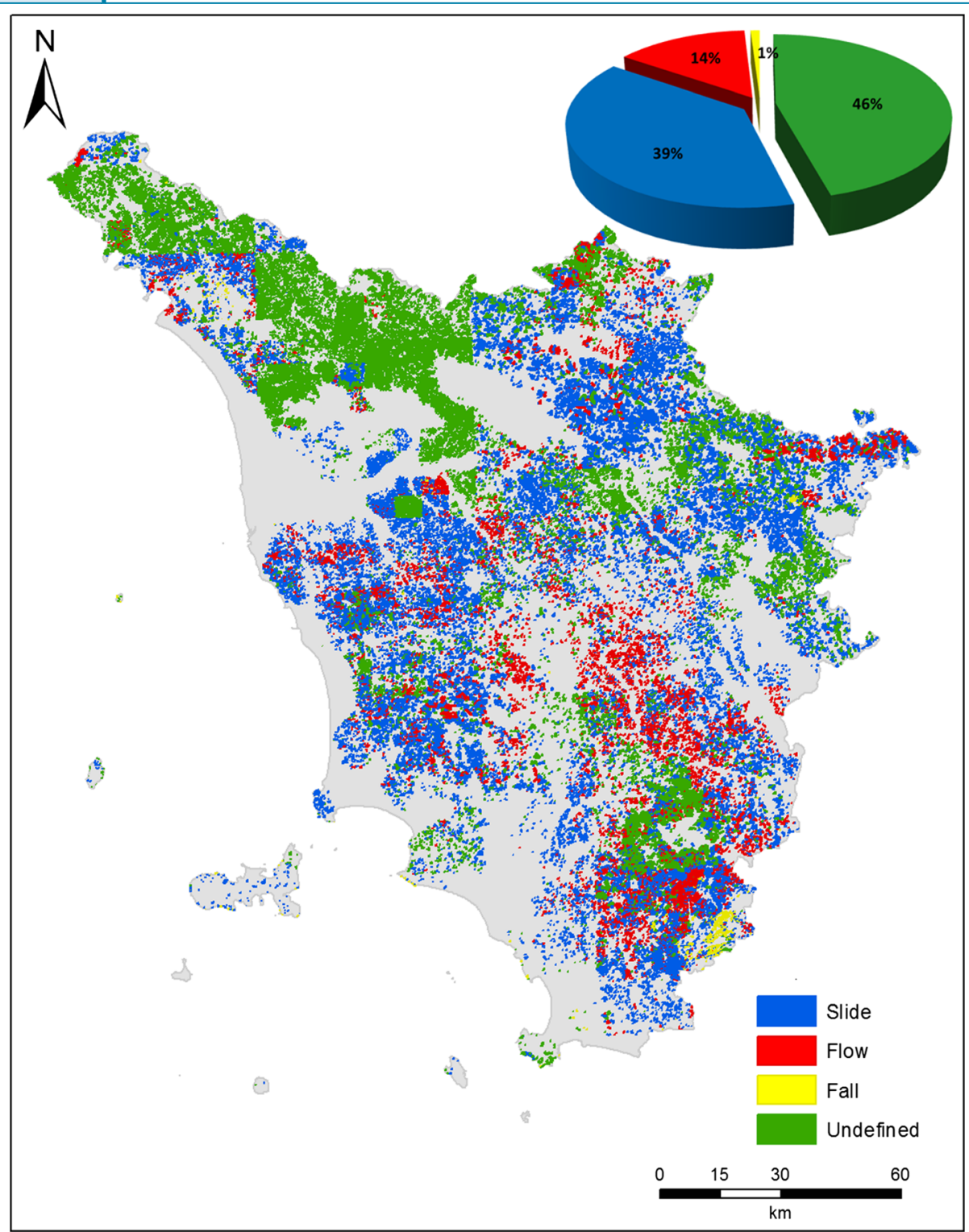

Fig. 5 Distribution of the new landslide inventory, classified on the basis of landslide type. Pie chart shows the distribution of landslide types

(Fig. 9c). Landslide density for each lithology has been analysed as well (Fig. 10). These analyses revealed that the most affected lithology by landslides is the marl-arenaceous flysch, where
$744 \mathrm{~km}^{2}$ of landslides are located ( $35.4 \%$ of all landslides), followed by pelitic flysch (ca. $344 \mathrm{~km}^{2}$ of landslides, $16.4 \%$ of all landslides) and marl-calcareous flysch (ca. $319 \mathrm{~km}^{2}$ of landslides, $15.2 \%$ of all

Table 2 Comparison between the previous landslide inventory and the updated one

\begin{tabular}{|c|c|c|c|c|c|c|}
\hline State of activity & $\begin{array}{l}\text { Former inventory } \\
\text { No of landslides (\%) }\end{array}$ & Area in $\mathrm{km}^{2}(\%)$ & $\begin{array}{l}\text { Updated inventory } \\
\text { No of landslides (\%) }\end{array}$ & Area in $\mathrm{km}^{2}(\%)$ & $\begin{array}{l}\text { Variation } \\
\text { No }\end{array}$ & Area $\left(\mathrm{km}^{2}\right)$ \\
\hline active & $12,048(13.2)$ & $180.7(8.6)$ & $12,720(13.9)$ & 239.1 (11.3) & 672 & 58.4 \\
\hline dormant & $68,821(75.3)$ & $1576(75)$ & $69,116(75.3)$ & $1578.4(74.9)$ & 295 & 2.4 \\
\hline Stabilized & $2024(2.2)$ & $169.5(8.1)$ & $1964(2.1)$ & $146.3(6.9)$ & -60 & -23.2 \\
\hline Relict & $2(0.0)$ & $0.2(0.0)$ & $2(0.0)$ & $0.2(0.0)$ & 0 & 0 \\
\hline Undefined & 8477 (9.3) & $174(8.3)$ & 7927 (8.6) & $142.8(6.8)$ & -550 & -31.2 \\
\hline Total & 91,372 & 2100.4 & 91,729 & 2106.8 & & \\
\hline
\end{tabular}




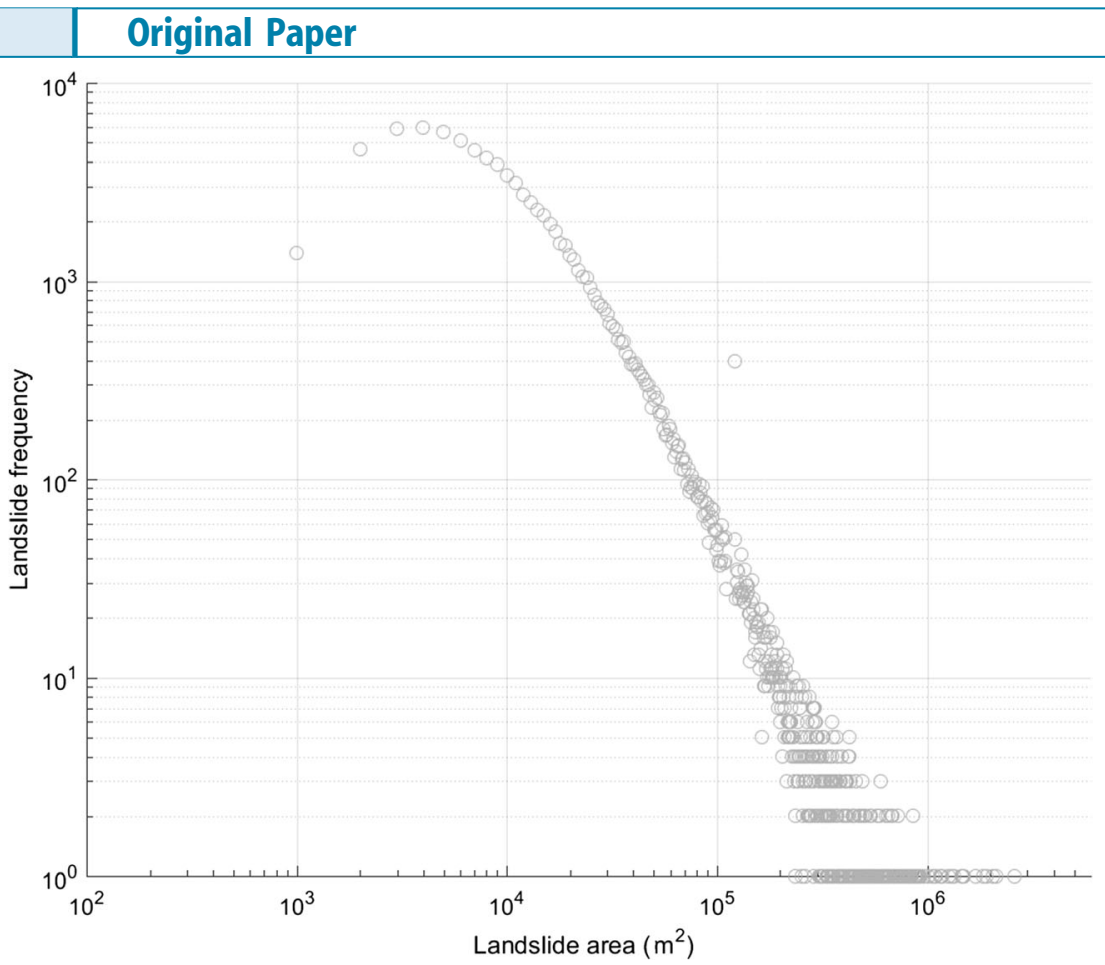

Fig. 6 Frequency-area distribution of the new landslide inventory in a log-log plot

landslides); to the other hand, the less represented lithologies are gypsum and anidrites $\left(6.6 \mathrm{~km}^{2}\right.$ of landslides, $0.3 \%$ of all landslides), intrusive rocks, gneiss and granulites $\left(2.9 \mathrm{~km}^{2}\right.$ of landslides, $0.1 \%$ of all landslides $)$ and glacial deposits $\left(4.1 \mathrm{~km}^{2}\right.$ of landslides, $0.2 \%$ of all landslides). This distribution only partially reflects the lithology's distribution, since most of the landslides are

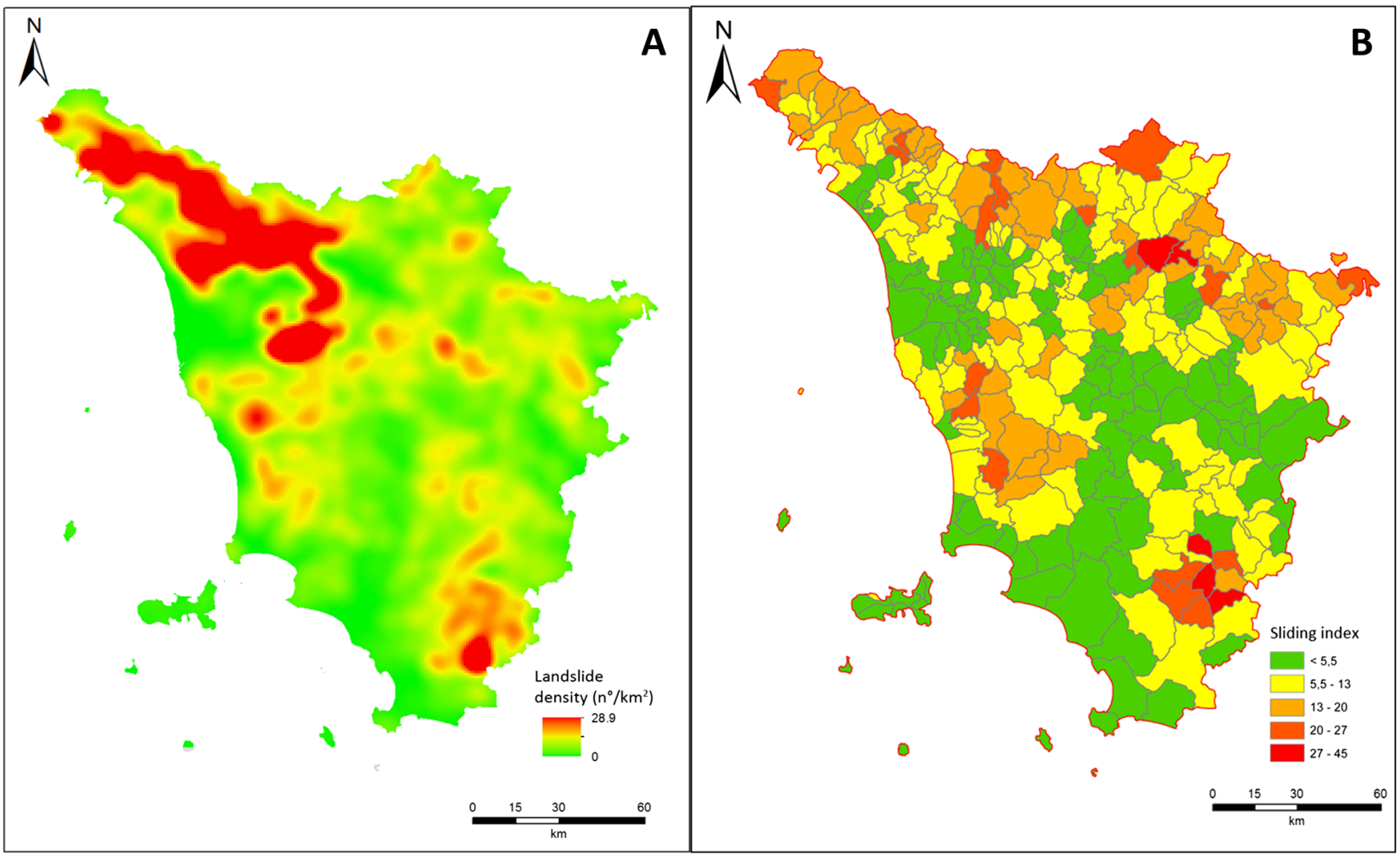

Fig. 7 Landslide density (a) and sliding index of Tuscany municipalities (b) 


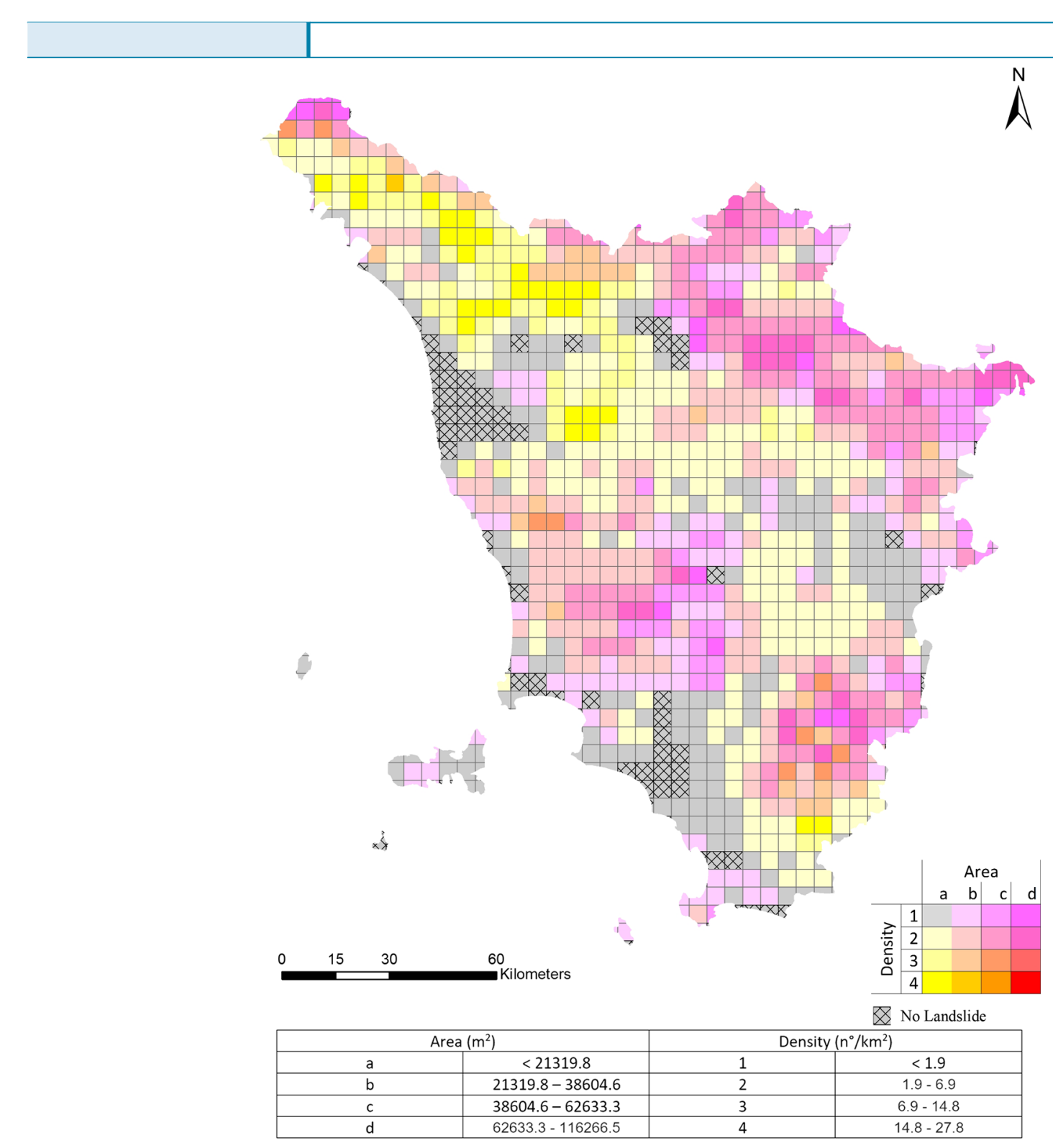

Fig. 8 Density-area distribution of landslides in Tuscany

in the most representative lithology (marl-arenaceous flysch), covering $26 \%$ of regional territory, but pelitic flysch cover only $7.5 \%$ of territory (with $16.4 \%$ of all landslides) and marl-calcareous flysch ca. $9.7 \%$ of it (with $15.2 \%$ of all landslides). Sand, sandstone and conglomerates and clay and clayey marls represent 14.2 and $12.2 \%$ of territory, respectively, but they are sensibly less affected by landslides than the other lithologies (ca $200 \mathrm{~km}^{2}$ for each one). Alluvial debris is the second most represented lithology (17.2\%), but only $44.6 \mathrm{~km}^{2}$ of landslides are present here $(2.1 \%$ of all landslides), since this lithology is mainly present in flat alluvial plains. These outcomes are summarized in the following Figure.

After lithology, the work moved to the analysis of several topographic factors, starting from the mean slope of landslides, as reported in the following figure (Fig. 11); it resulted that in general, most landslides are located in slope with inclination around $10^{\circ}-15^{\circ}$, whereas falls present a peak frequency in steeper slopes $\left(\right.$ ca. $30^{\circ}-35^{\circ}$ ).
Subsequently, the slope curvature has been investigated. Curvature is calculated as second derivative of slope gradient and indicates the shape of the slopes: negative values represent concave slopes, positive values represent convex slopes. In this case, both mean curvature and curvature range of landslides have been calculated. Mean curvature (Fig. 12) has been used to identify the more representative slope shape (concave or convex) and range (Fig. 13) has been used to highlight how the slope shape is complex (range values close to o represent flat or homogeneous slopes, high range values represent wavy slopes). By this analysis, it resulted that majority of landslides are on gently concave slopes, with mean curvature slightly lower than zero and curvature range slightly higher the zero.

Lastly, the soil use in landslide areas has been analysed, using Corine Land Cover (level II) dataset (land.copernicus.eu/pan-european/corine-land-cover). In this case, as for lithologies, we explored at first the landslide area for each soil use class (Fig. 14a); 

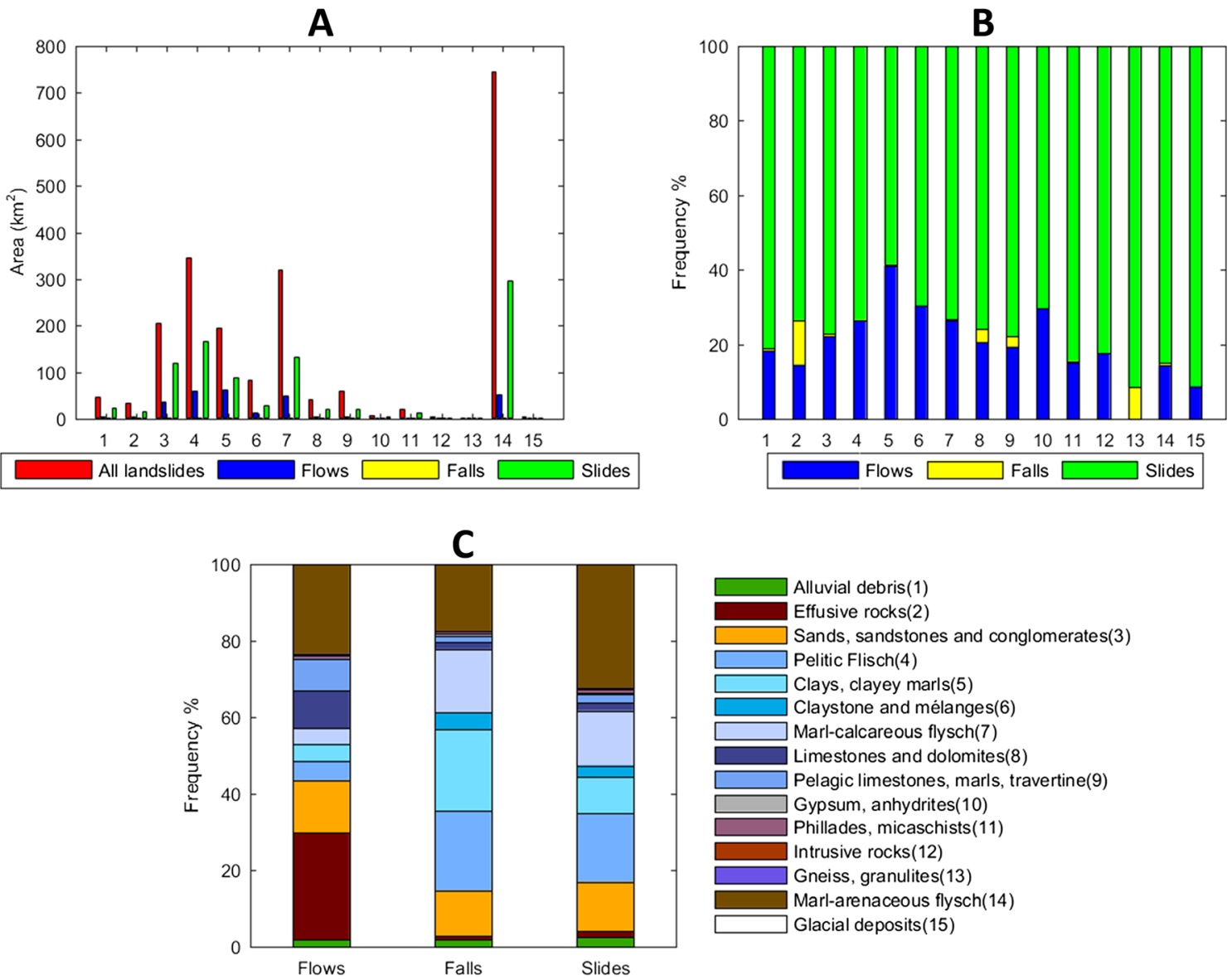

Fig. 9 a Landslide area for each lithology. b Landslide distribution on lithological basis. $\mathbf{c}$ Lithology distribution for each type of landslide

then, the analysis was focused on the three main types of landslide, analysing both the landslide types for each class of soil use falling into landslides area (Fig. 14b) and the soil use distribution for each landslide type (Fig. 14c).
Discussion

In this paper, we presented the updated landslide inventory map of Tuscany region and the analysis of landslide features. The updating has been performed using PSInSAR data, which are a

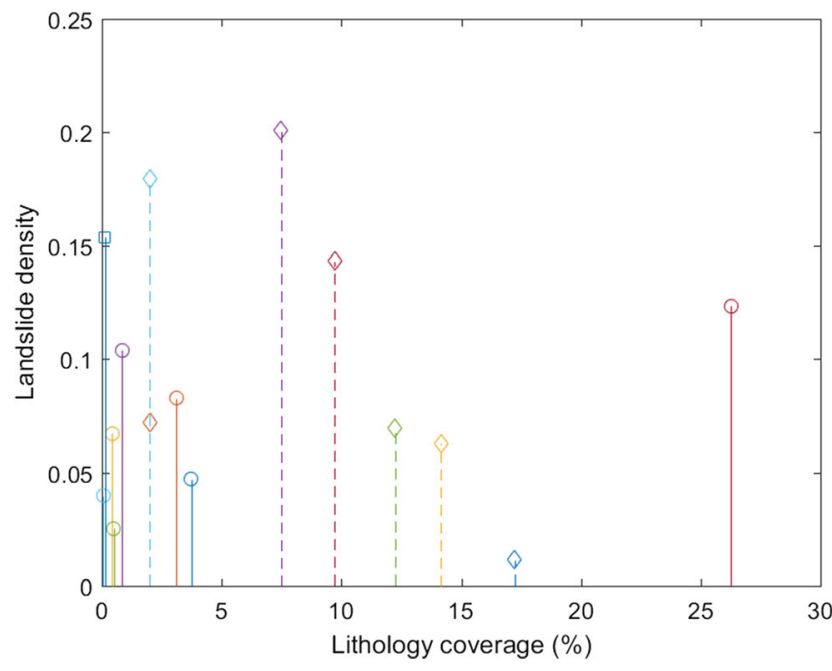

\begin{tabular}{|ll|}
\hline$--\ominus$ & alluvial deposits. detritus \\
$--\ominus$ & effusive rocks \\
$--\ominus$ & Sandstones and conglomerates \\
$--\ominus$ & Pelitic flysch \\
$--\ominus$ & Clays. clayey marls \\
$--\ominus$ & Claystones and mélanges \\
$--\ominus$ & Marl-calcareous flysch \\
$\ominus$ & Limestones and dolomites \\
$\ominus$ & Pelagic limestones. marls. travertines \\
$\ominus$ & Gypsum. anhydrites \\
$\ominus$ & Phillades. Micaschists \\
$\ominus$ & Intrusive rocks \\
$\ominus$ & Gneiss. granulites \\
$\square$ & Marl-arenaceous flysch \\
\hline
\end{tabular}

Fig. 10 Comparison between lithology coverage and landslide density 

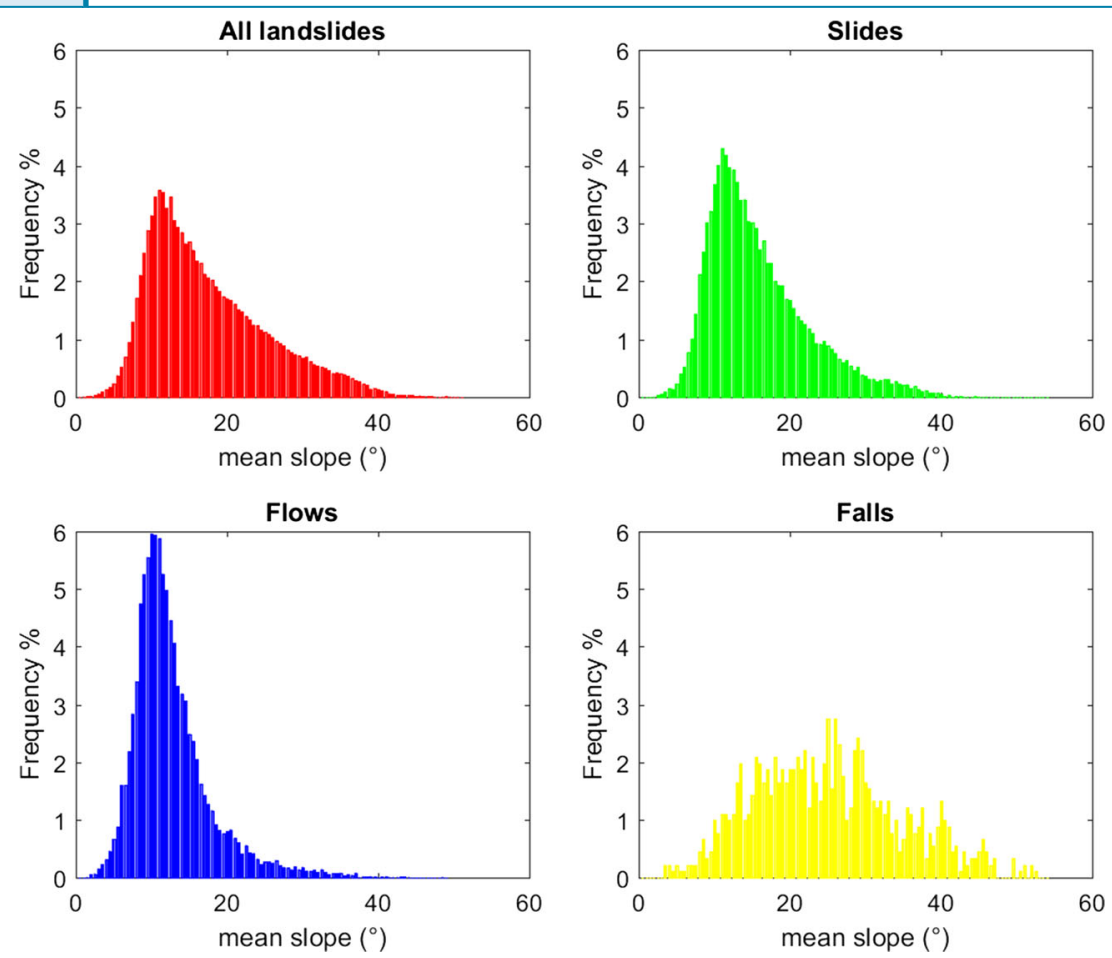

Fig. 11 Frequency distribution of mean slope gradient of landslides

powerful instrument for landslide detection and analysis, but present also some well-known limitations, such as no data over highly vegetated areas or the impossibility of detecting movements which are orthogonal to the LOS of satellites. On one hand, PSInSAR allows to map a large number of landslides in short time
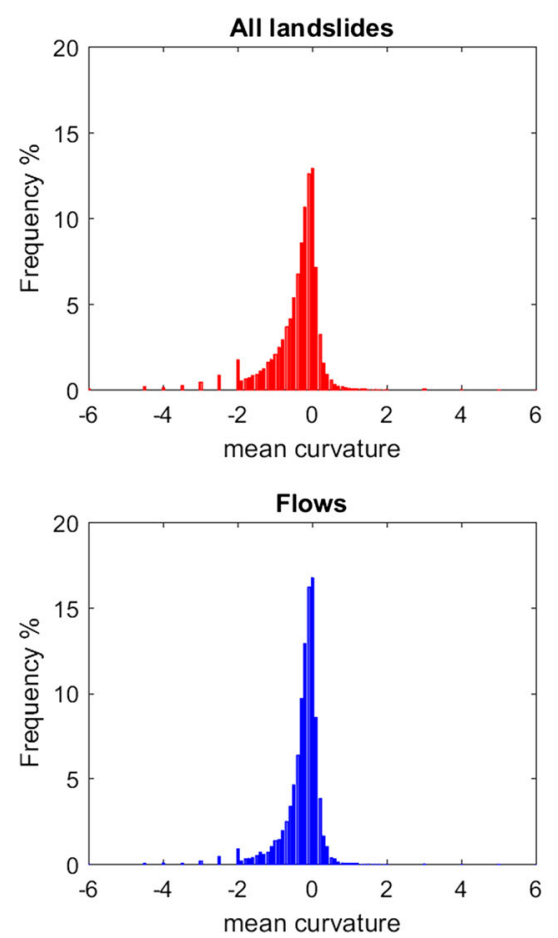

and in hardly accessible areas; on the other hand, its limitations could lead to underrate the real number of active or dormant landslides, since recent movement could be underestimated or undetected. One more limitation of this technique is the spatial distribution of permanent scatterers, since their density is usually
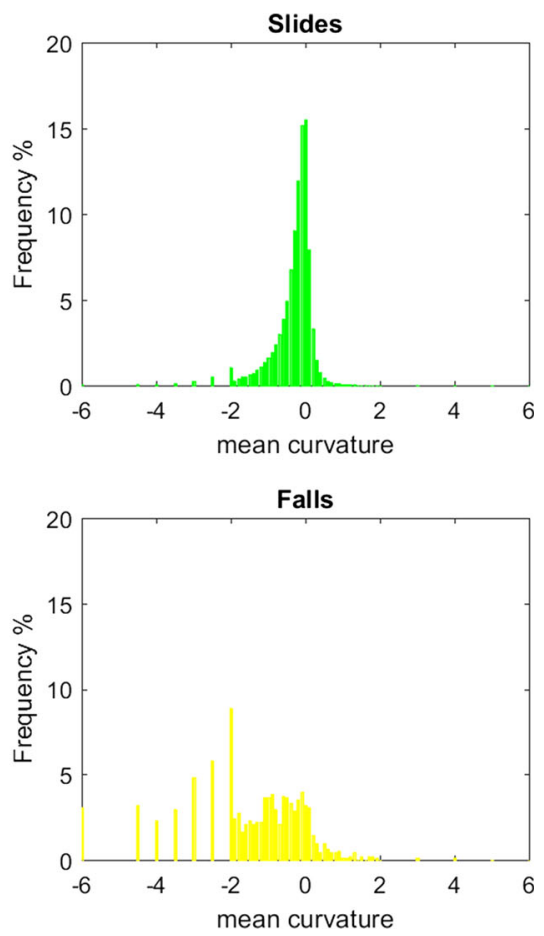

Fig. 12 Frequency distribution of mean curvature of landslides 

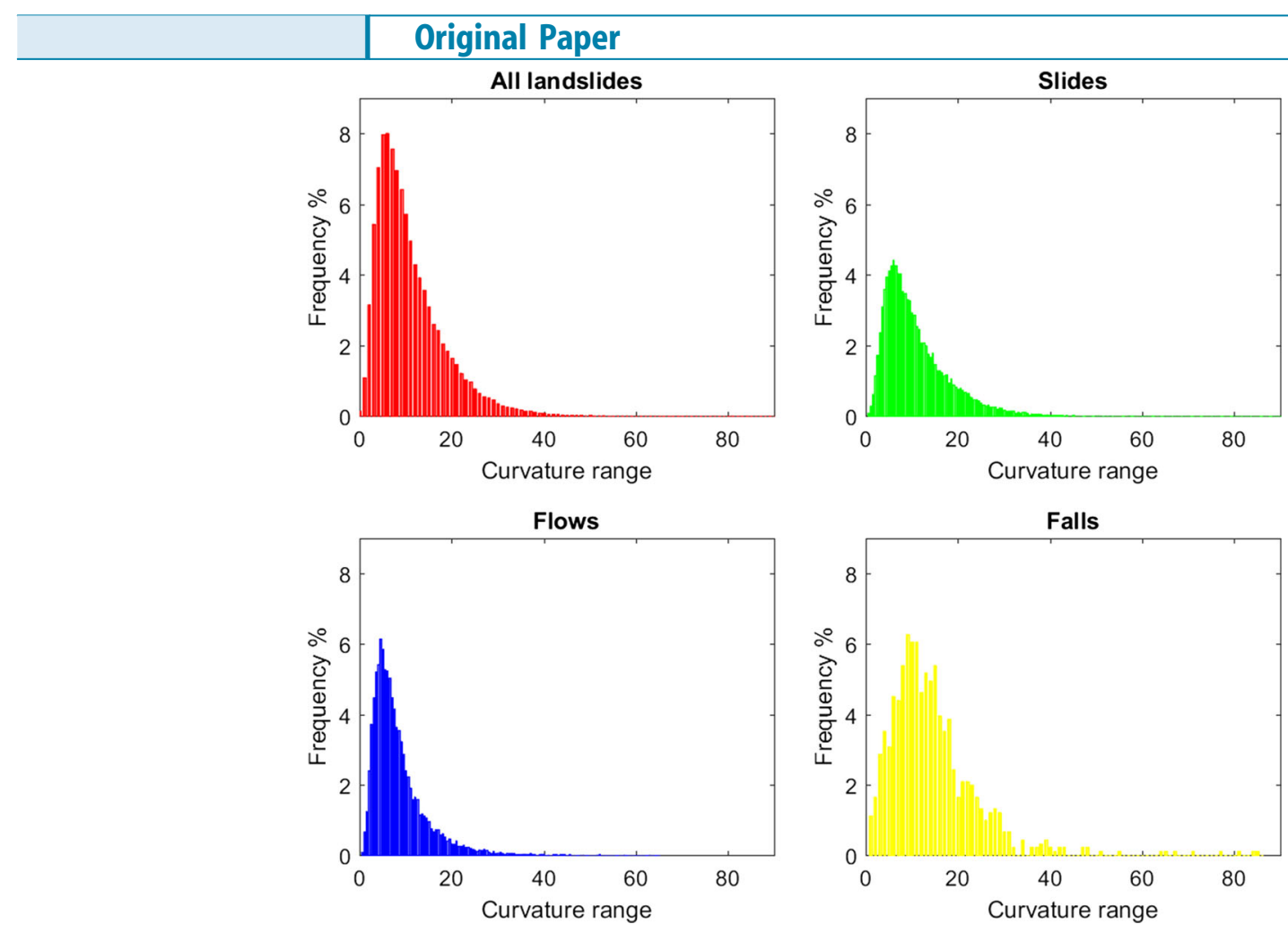

Fig. 13 Frequency distribution of curvature ranges of landslides

very high in correspondence of cities and facilities (usually in plain areas), but sensibly lower in low populated or wood areas as mountainous areas, where most of landslide could occur. Even with these limitations, the new inventory is characterized by a marked increase in active landslides, with a reduction of stabilized and unclassified landslides.

A classical area/frequency distribution analysis has been performed and resulted in a classical log-normal distribution of landslides, with a rollover at ca. $1^{*} 10^{4} \mathrm{~m}^{2}$. This distribution also shows a spreading of low frequencies over a wide range of areas, for values higher than $2 * 10^{5} \mathrm{~m}^{2}$; this is due to the presence of few landslides in several intervals (each interval is $1000 \mathrm{~m}^{2}$ ).

Landslide density and sliding index have been calculated to identify more landslide-prone area, which obviously resulted in mountainous areas. An exception is represented by the hilly area in the central-western part of the region, where a high landslide density has been observed, but related to a slow sliding index of the municipalities of this area. This could be due both to the high number of small municipalities, which fragments the number of landslides for each of them, leading to the decreasing of sliding index, and to the presence of a high number of small landslides, so that the density increased and at the same time the sliding index decreased.

In this work, a landslide density-area map has been proposed, since for a proper urban planning, not only the number of landslides is useful, but also their dimension should be considered. The proposed map can represent and useful tool to improve the knowledge about dimension and density of landslides (i.e. a certain area is affected by a high density of small landslides), but it does not provide any specific information about the landslide dimension, type or state of activity. In urban planning purpose, a joint use of this map and of the landslide inventory could be very useful and give a quite accurate overview of the landslide setting of a certain area.

This analysis revealed that the north-western part of the region is characterized by high density of small landslide (mainly undefined type), in correspondence of mainly clayey lithologies, while the north-eastern part, mainly characterized by marl-arenaceous flysch, is affected by low density of large landslides (mainly slides), as well as the southern part of the region, where intrusive rocks crop out.

After the spatial analysis of landslides, we compared the landslides with several features, starting the lithology of the landsliding areas. It resulted that pelitic flysch is the most prone to landslide lithology since it has the highest landslide density, followed by Claystones and mélanges and Marl-calcareous flysch. Even if slide is everywhere the most present type of landslide, it can be pointed out that flows represent $40 \%$ of all landslides in clays and clayey marls, while falls represent ca. $10 \%$ of all landslides in effusive rocks and in gneiss and granulites.

The analysis of mean slope gradient of landslides revealed that there are no landslides in plain areas (it is obvious) and in general landslides are mainly located in slopes ranging around $10^{\circ}-15^{\circ}$. Falls show a different distribution, since peak frequencies are around $30^{\circ}-35^{\circ}$, with some falls also in steeper slopes, around at $50^{\circ}-55^{\circ}$.

The analysis of slope curvature has been performed considering both the mean curvature and the curvature range, to explore the shape of the slopes affected by landslides. Mean curvature has been calculated to investigate the more representative slope shape 

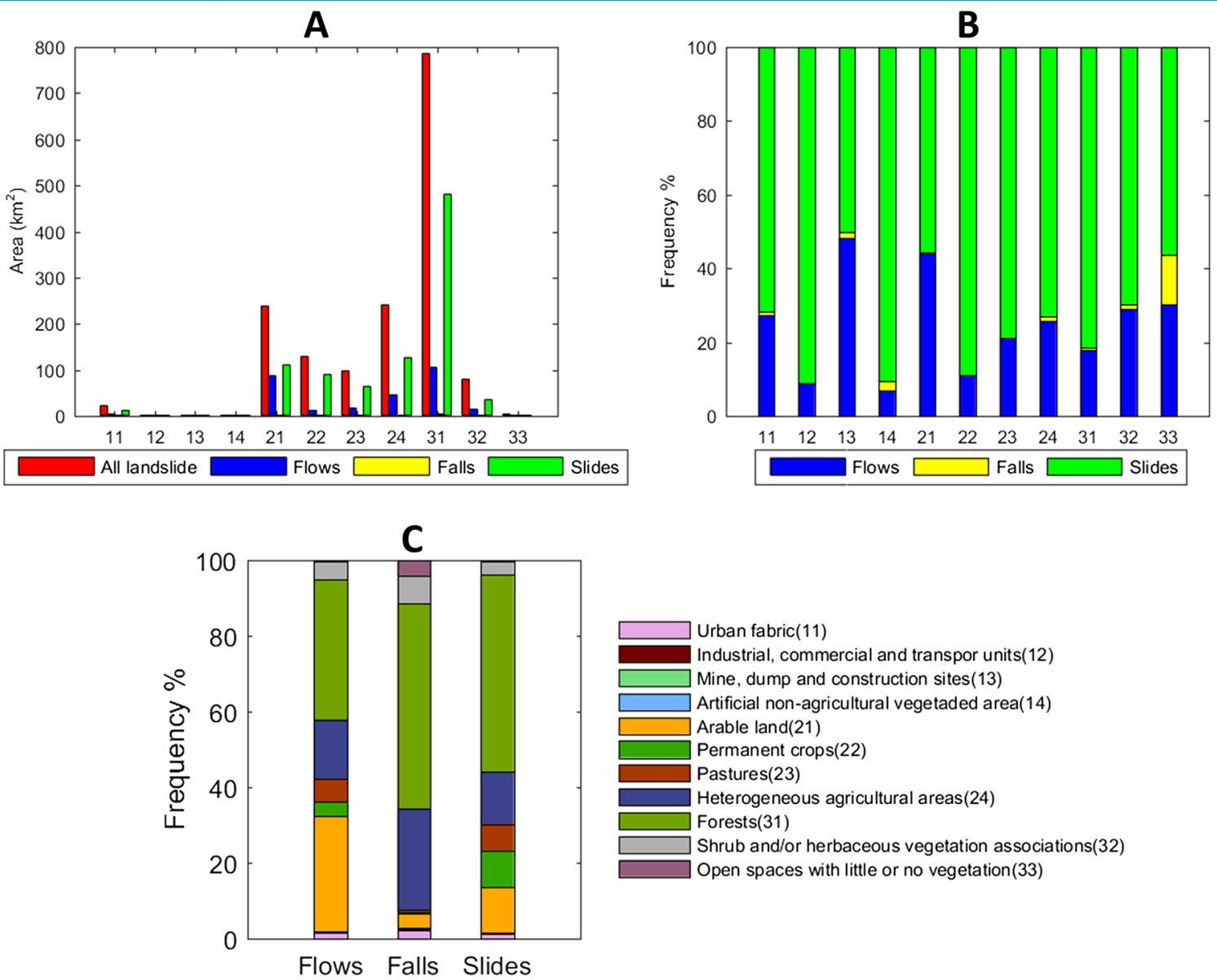

Urban fabric(11)

Industrial, commercial and transpor units(12)

Mine, dump and construction sites(13)

Artificial non-agricultural vegetaded area(14)

Arable land(21)

Permanent crops(22)

Pastures(23)

Heterogeneous agricultural areas(24)

Forests(31)

Shrub and/or herbaceous vegetation associations(32)

Open spaces with little or no vegetation(33)

Fig. 14 a Landsliding area for each soil use class. b Landslide frequency for each soil use class. c Soil use frequency for the three main kinds of landslides

(concave or convex) and curvature range has been used to highlight the complexity of slopes, where range values close to 0 represent flat or homogeneous slopes, high range values represent wavy slopes.

By the analysis of mean slope curvature, it resulted that in general, landslides are in plain or gently concave slopes; falls present a different distribution, since they are more equally distributed than other types of landslides.

Curvature ranges showed that landslides are mainly located in slightly wavy, but not plain, slopes, with range values mainly under 20.

At the end, the soil use of landslides has been analysed; we explored the types of landslide for each class of soil use falling into landslide areas and the soil use distribution for each landslide type. It resulted that all types of landslide are mainly in forest areas (class 31). It also resulted that slides are the most represented landslide type in all soil uses, with a clear predominance in the classes 14 (Artificial non-agricultural vegetated areas) and 22 (Permanent crops), where they represent about $90 \%$ of all landslides.

\section{Conclusions}

In this paper, the updating and the exploration of the Tuscany landslide inventory have been presented.

The inventory updating has been performed using PSInSAR data, freely distributed by the Italian government, and several ancillary data, as DTM and derivative maps, lithological and topographic maps.

This procedure leads to a reduction of unclassified landslides $(-550)$ and allowed to identify 672 active landslides. This new inventory consists of ca. 91,700 landslides, mainly slides (39\%), followed by flows (14\%) and fall (1\%) and $46 \%$ of unclassified landslides.

Types of landslide distribution could also be influenced by the criteria used for the first creation of the inventory, since some anomalous clusters can be highlighted (cfr. Fig. 5), such as in NW part of the region, where almost all landslides were classified as undefined. In this area, close to the coast, is also present a square cluster with mainly slides. These differences could be due to different techniques used to map landslides, but also to different approach or to the judgement of the scientists.

This new landslide database has been subsequently analysed, moving from a classical frequency distribution analysis. Sliding index of all municipalities has been calculated and compared to the landslide density map; subsequently, a map summarizing both dimension and density of landslide has been elaborated.

After that, we explored the landslide distribution considering several factors, starting from lithology, where it resulted that pelitic flysch is the most landslide-prone lithology. An analysis of elevation, slope gradient, slope curvature and soil use of landslide has been performed as well. 
Open Access This article is distributed under the terms of the Creative Commons Attribution 4.0 International License (http:// creativecommons.org/licenses/by/4.o/), which permits unrestricted use, distribution, and reproduction in any medium, provided you give appropriate credit to the original author(s) and the source, provide a link to the Creative Commons license, and indicate if changes were made.

\section{References}

Agostini A, Tofani V, Nolesini T, Gigli G, Tanteri L, Rosi A, Cardellini S, Casagli N (2014) A new appraisal of the Ancona landslide based on geotechnical investigations and stability modeling. Q J Eng Geol Hydrogeol 47:29-43. doi:10.1144/qjegh2013-028

Antonini G, Cardinali M, Guzzetti F, Reichenbach P, Sorrentino A (1993) Carta Inventario dei Fenomeni Franosi della Regione Marche ed aree limitrofe. CNR, Gruppo Nazionale per la Difesa dalle Catastrofi Idrogeologiche, Publication n. 580, 2 sheets, scale 1:100,000, (in Italian)

Bă Iteanu V, Chendeș M, Sima P, Enciu A (2010) Country-wide spatial assessment of landslide susceptibility in Romania. Geomorphology 124:102-112

Berardino P, Fornaro G, Lanari R, Sansosti E (2003) A new algorithm for surface deformation monitoring based on small baseline differential SAR interferograms. IEEE Trans Geosci Remote Sens 40:2375-2383

Bicocchi G, D'Ambrosio M, Rossi G, Rosi A, Tacconi-Stefanelli C, Segoni S, Nocentini M, Vannocci P, Tofani V, Casagli N, Catani F (2016) Geotechnical in situ measures to improve landslides forecasting models: A case study in Tuscany (Central Italy). doi:10.1201/b21520-42

Bortolotti V (1992) The Tuscany-Emilian Apennine. Regional geological guidebook, Vol. 4, S.G.I. BEMA Editrice, 329pp. (in Italian)

Brabb EE, Pampeyan EH (1972) Preliminary map of landslide deposits in San Mateo County, California. U.S. Geological Survey Miscellaneous Field Studies Map, MF-344

Brabb EE, Harrod S (1989), Landslides: extent and economic significance. Proceedings of the 28th International Geological Congress: Symposium on Landslides 17 Jul 1989 Washington, DC (USA)

Brabb EE (1991) The world landslide problem. Episodes 14(1):52-61

Brunsden D (1985) Landslide types, mechanisms, recognition, identification. In: Morgan CS (ed) Landslides in the south wales coalfield, proceedings symposium, the polytechnic of wales, pp. 19-28

Brunsden D (1993) Mass movement; the research frontier and beyond: a geomorphological approach. Geomorphology 7(1):85-128

Cardinali M, Guzzetti F, Brabb EE (1990) Preliminary map showing landslide deposits and related features in New Mexico. U.S. Geological Survey Open File Report 90/293, 4 sheets, scale 1:500,000

Cardinali M, Antonini G, Reichenbach P, Guzzetti F (2001) Photo geological and landslide inventory map for the upper Tiber River basin. CNR, Gruppo Nazionale per la Difesa dalle Catastrofi Idrogeologiche, Publication n 2116, scale 1:100,000

Cardinali M. Carrara A, Guzzetti F, Reichenbach P (2002) Landslide hazard map for the upper Tiber River basin. CNR, Gruppo Nazionale per la Difesa dalle Catastrof Idrogeologiche, Publication n. 2634, scale 1:100,000

Cardinali M, Galli M, Guzzetti F, Ardizzone F, Reichenbach P, Bartoccini P (2006) Rainfal induced landslides in December 2004 in south-western Umbria, central Italy: types, extent, damage and risk assessment. Nat Hazards Earth Syst Sci 6:237-260

Casu F, Manzo M, Lanari R (2006) A quantitative assessment of the SBAS algorithm performance for surface deformation retrieval. Remote Sens Environ 102:195-210

Cheng K, Wei C, Chang S (2004) Locating landslides using multi-temporal satellite images. Adv Space Res 33(3):296-301

Ciampalini A, Raspini F, Lagomarsino D, Catani C, Casagli N (2016) Landslide susceptibility map refinement using PSInSAR data. Remote Sens Environ 184:302-315

Colesanti C, Ferretti A, Prati C, Rocca F (2003) Monitoring landslides and tectonic motions with the permanent scatterers technique. Eng Geol 68:3-14

Colesanti C, Wasowski J (2006) Investigating landslides with space-borne synthetic aperture radar (SAR) interferometry. Eng Geol 88:173-199

Crosetto M, Biescas E, Duro J, Closa J, Arnaud A (2008) Generation of advanced ERS and Envisat interferometric SAR products using the stable point network technique. Photogramm Eng Remote Sens 74:443-451

Cruden DM, Varnes DJ (1996) Landslide types and processes. In: Turner AK, Schuster RL (eds) Landslides - investigation and mitigation. National Research Council, Transportation Research Board, National Academy Press, Washington DC, pp 36-75
Dai FC, Xua C, Yaob X, Xua L, Tua XB, Gongc QM (2010) Spatial distribution of landslides triggered by the 2008 Ms 8.0 Wenchuan earthquake. J Asian Earth Sci 40(3):883-895

Dai FC, Lee CF (2001) Frequency-volume relation and prediction of rainfall-induced landslides. Eng Geol 59:253-266

Delaunay J (1981) Carte de France des zones vulnèrables a des glissements, écroulements, affaissements et effrondrements de terrain. Bureau de Recherches Géologiques et Minières, 8, SGN 567 GEG, 23 pp. (in French)

Duman TY, Çan T, Emre Ö, Keçer M, Doğan A, S erafettin A, Serap D (2005) Landslide inventory of northwestern Anatolia. Turkey Eng Geol 77(1-2):99-114

Dussauge C, Grasso JR, Helmstetter A (2003) Statistical analysis of rockfall volume distributions: implications for rockfall dynamics. J Geophys Res. doi:10.1029/2001JB000650

Dussauge-Peisser C, Helmstetter A, Grasso JR, Hantz D, Desvarreux P, Jeannin M, Giraud A (2002) Probabilistic approach to rock fall hazard assessment: potential of historical data analysis. Nat Hazards Earth Syst Sci 2(1/2):15-26

Farina P, Colombo D, Fumagalli A, Marks F, Moretti S (2006) Permanent Scatterers for landslide investigations: outcomes from the ESA-SLAM project. Eng Geol 88:200-217

Fell R, Glastonbury J, Hunter G (2007) Rapid landslides: the importance of understanding mechanisms and rupture surface mechanics. Q J Eng Geol Hydrogeol 40(1):9-27

Ferretti A, Prati C, Rocca F (2000) Nonlinear subsidence rate estimation using permanent Scatterers in differential SAR interferometry. IEEE Trans Geosci Remote Sens 38:22022212

Ferretti A, Fumagalli A, Novali F, Prati C, Rocca F, Rucci A (2011) A new algorithm for processing interferometric data-stacks: SqueeSARTM. IEEE Trans Geosci Remote Sens 99:1-11

Fujii Y (1969) Frequency distribution of landslides caused by heavy rainfall. J Seismol Soc Jpn 22:244-247

Guzzetti F, Cardinali M, Reichenbach P (1996) The influence of structural setting and lithology on landslide type and pattern. Environ Eng Geosci 2(4):531-555

Guzzetti F, Malamud BD, Turcotte DL, Reichenbach P (2002) Power-law correlations of landslide areas in central Italy. Earth Planet Sci Lett 195:169-183

Guzzetti F, Reichenbach P, Cardinali M, Galli M, Ardizzone F (2005) Probabilistic landslide hazard assessment at the basin scale. Geomorphology 72:272-299

Guzzetti F, Galli M, Reichenbach P, Ardizzone F, Cardinali M (2006a) Landslide hazard assessment in the Collazzone area, Umbria, central Italy. Nat Hazards Earth Syst Sci 6:115-131

Guzzetti F, Reichenbach P, Ardizzone F, Cardinali M, Galli M (2006b) Estimating the quality of landslide susceptibility models. Geomorphology 81:166-184

Guzzetti F, Mondini AC, Cardinali M, Fiorucci M, Santangelo M, Chang KT (2012) Landslide inventory maps: new tools for an old problem. Earth-Sci Rev 112:1-25

Herrera G, Notti D, Garcia-Davalillo JC, Mora 0, Cooksley G, Sanchez M, Arnaud A, Crosetto M (2011) Analysis with C- and X-band satellite SAR data of the Portalet landslide area. Landslides 8:195-206

Hervas J, Barredo Jl, Rosin PL, Pasuto A, Mantovani F, Silvano S (2003) Monitoring landslides from optical remotely sensed imagery: the case history of Tessina landslide, Italy. Geomorphology 54(1):63-75

Hervás J (2012). Landslide inventory. In: Bobrowky PT (ed), Encyclopedia of natural hazards Springer Heidelberg

Hooper A, Segall P, Zebker H (2007) Persistent scatterer interferometric synthetic aperture radar for crustal deformation analysis, with application to Volcan Alcedo, Galapagos. Geophys Res 112:B07407

Hovius N, Stark CP, Allen PA (1997) Sediment flux from a mountain belt derived by landslide mapping. Geology 25:231-234

Jenks G (1967) The data model concept in statistical mapping. Int Yearb Cartograph 7:186-190

Lu P, Stumpf A, Kerle N, Casagli N (2011) Object-oriented change detection for landslide rapid mapping. IEEE Geosci Remote Sens Lett 8(4):701-705

Lu P, Casagli N, Catani F, Tofani V (2012) Persistent Scatterers Interferometry Hotspot and Cluster Analysis (PSI-HCA) for detection of extremely slow-moving landslides. Int J Remote Sens 33(2):466-489

Malamud BD, Turcotte DL, Guzzetti F, Reichenbach P (2004a) Landslides, earthquakes and erosion. Earth Planet Sci Lett 229:45-59

Malamud BD, Turcotte DL, Guzzetti F, Reichenbach P (2004b) Landslide inventories and their statistical properties. Earth Surf Process Landf 29(6):687-711

Martha TR, Kerle N, Jetten V, van Westen CJ, Kumar KV (2010) Characterizing spectral, spatial and morphometric properties of landslides for semi-automatic detection using object-oriented methods. Geomorphology 116(1):24-36

Meisina C, Notti D, Zucca F, Ceriani M, Colombo A, Poggi F, Roccati A, Zaccone A (2013) The use of PSInSARTM and SqueeSARTM techniques for updating landslide inventories. In: Margottini, Canuti, Sassa (eds) landslide science and practice, volume 1: landslide inventory and susceptibility and hazard zoning, pp 81-87 
Mora 0, Mallorqui JJ, Broquetas A (2003) Linear and nonlinear terrain deformation maps from a reduced set of interferometric SAR images. IEEE Trans Geosci Remote Sens 41:2243-2253

Nichol J, Wong M (2005) Satellite remote sensing for detailed landslide inventories using change detection and image fusion. Int J Remote Sens 26(9):1913-1926

Radbruch-Hall DH, Colton RB, Davies WE, Lucchitta I, Skipp BA, Varnes D.J (1982) Landslide overview map of the conterminous United States. U.S. Geological Survey Professional Paper, 1183

Parker RN, Densmore AL, Rosser NJ et al (2011) Mass wasting triggered by the 2008 Wenchuan earthquake is greater than orogenic growth. Nat Geosci 4(7):449-452

Raspini F, Bardi F, Bianchini S et al (2017) The contribution of satellite SAR-derived displacement measurements in landslide risk management practices. Nat Hazards. doi:10.1007/s11069-016-2691-4

Righini G, Pancioli V, Casagli N (2012) Updating landslide inventory maps using persistent scatterer interferometry (PSI). Int J Remote Sens 33(7):2068-2096

Rib HT, Liang T (1978) Recognition and identification. In: Schuster RL, Krizek R (eds) Landslide analysis and control. Transportation research board special report 176. National Academy of Sciences, Washington, DC, pp 34-80

Romeo R, Tiberi P, Floris M, Mari M, Perugini P, Pappafico G, Veneri F (2006) Indagine sui rapporti esistenti tra uso del suolo e dissesto idrogeologico nella Regione Marche. Giornale di Geologia Applicata 4:253-256. doi:10.1474/GGA.2006-04.0-33.0161 (in italian)

Rosi A, Segoni S, Catani F, Casagli N (2012) Statistical and environmental analyses for the definition of a regional rainfall threshold system for landslide triggering in Tuscany (Italy). J Geogr Sci 22(4):617-629

Rosi A, Agostini A, Tofani V, Casagli N (2014) A procedure to map subsidence at the regional scale using the persistent scatterer interferometry (PSI) technique. Remote Sens 6:10510-10522

Rosi A, Tofani V, Agostini A, Tanteri L, Stefanelli CT, Catani F, Casagli N (2016) Subsidence mapping at regional scale using persistent scatters interferometry (PSI): the case of Tuscany region (Italy). Int J Appl Earth Obs Geoinf 52:328-337

Strozzi T, Wegmuller U, Keusen HR, Graf K, Wiesmann A (2006) Analysis of the terrain displacement along a funicular by SAR interferometry. IEEE Trans Geosci Remote Sens 3:15-18
Tofani V, Del Ventisette C, Moretti S, Casagli N (2014) Integration of remote sensing techniques for intensity zonation within a landslide area: a case study in the northern Apennines, Italy. Remote Sens 6(2):907-924

Turner AK, Schuster RL (1996), Landslides: investigation and mitigation, National Academic Press, Washington, D C, Special Report, 247:12-36

Trigila A, ladanza C, Spizzichino D (2010) Quality assessment of the Italian landslide inventory using GIS processing. Landslides 7:455-470

Vai GB, Martini IP (2001) Anatomy of an Orogen: the Apennines and adjacent Mediterranean basins. Kluver Academic Publishers, Dortdrecht 632pp

Van Den Eeckhaut M, Poesen J, Verstraeten G, Vanacker V et al (2007) Use of LIDAR-derived images for mapping old landslides under forest. Earth Surf Process Landf 32:754-769

Van Westen CJ, Van Asch TWJ, Soeters R (2006) Landslide hazard and risk zonation why is it still so difficult? Bull Eng Geol Environ 65:167-184

Van Westen CJ, Castellanos Abella EA, Sekhar LK (2008) Spatial data for landslide susceptibility, hazards and vulnerability assessment: an overview. Eng Geo 102:112-131

Vilardo G, Ventura G, Terranova C, Matano F, Nardò S (2009) Ground deformation due to tectonic, hydrothermal, gravity, hydrogeological, and anthropic processes in the Campania region (southern Italy) from permanent scatterers synthetic aperture radar interferometry. Remote Sens Environ 113:197-212

Werner C, Wegmuller U, Strozzi T, Wiesmann A (2003) Interferometric point target analysis for deformation mapping. In: Proceedings of IEEE International Geoscience and Remote Sensing Symposium (IGARSS'03), Toulouse, France, 21-25 July, 2003, pp. 4362-4364

WP/WLI (1993) Multilingual landslide glossary. International geotechnical societies' UNESCO working party on world landslide inventory (chairman D Cruden). BiTech, Richmond, p 59

A. Rosi $(\square) \cdot$ V. Tofani $\cdot$ L. Tanteri $\cdot$ C. Tacconi Stefanelli $\cdot$ A. Agostini

F. Catani - N. Casagli

Department of Earth Sciences,

University of Firenze,

Firenze, Italy

e-mail: ascanio.rosi@unifi.it 